tional interpretations of the western American frontier by demonstrating that cross dressing was a part of everyday life on the frontier between 1850 and 1920. Through his analysis of male-to-female and female-to-male cross dressers in rural areas, Boag situates the construction of gender and sexual identities outside of the urban milieu at the turn of the twentieth century.

Carly Simpson

York University

\title{
Chaia Heller, Food, Farms and Solidarity: French Farmers Challenge Industrial Agriculture and Genetically Modified Crops (Durham \& London, Duke University Press, 2013).
}

Chaia Heller in Food, Farms and Solidarity explores the producer-led French farm union Confédération Paysanne with attention to the how the union organizes campaigns, articulates their messages and cultivates solidarity across France and to the global movement against Genetically Modified Organisms (GMO) and Industrial farming. As an American anthropologist, Heller places herself in France, as both an observer and a participant of the union combining historical research, personal interviews and her first person accounts.

Heller traces the activities and actors of the union over a decade from the early 1990 s to the early 2000 s as a social movement fighting to be recognized in France as the post-industrial alternative to food production. The union emerged in 1987 to represent farmers outside of the large-scale industrial model which was the preference of the existing farming union, fédération nationale des syndicats d'exploitants agricoles (FNSEA). The union stems from what Heller describes as the 'new paysan movement' beginning in the late 1960's with the emergence of a paysan (peasant farmer) identity as an important social-cultural entity that countered the notion that small-holder farmers were disappearing and dispensable during an era of rapid industrial agricultural growth in France. After its inception, the union grew to a large organization presenting a collective vision of 'alter-globalization' offering alternatives to the neoliberal commodification of food.

Heller examines the union's success in capturing the public's attention and ultimately influencing France's food policies, with an eventual national moratorium on GMO's. The unions approach to appealing to French society's values and cultural frameworks was the basis for their success. The union drew on various tactics such as producing policy reports on GMO's and on the other side orchestrating several high profile direct actions. The movement overtime became known for their commitment to preserving rural communities and landscapes, combating the spread of American style junk food and fast food chains and preserving small farms that produced culturally relevant traditional foods. 
Heller pays particular attention to the leaders whom emerge over the course of her study and how they influence the union and draw public support. Key figures are Guy Le Fur, René Resiel and José Bové. These men represent different ideological focuses of the organization, from Le Fur's emphasis influencing government policy, Resiel's commitment to political-socialist beliefs and finally Bové's rise as an international alter-globalization personality. Bové is extensively reviewed as a prominent activist and a sheep farmer from southern France that is a producer of the artisanal Roquefort cheese, a food product that becomes a political tool for the paysans. During the course of Heller's study, Bové gathers increasing media attention in France for his direct action campaigns targeting McDonalds restaurants and then subsequently GMO test fields. His organizing of the dismantling of a partially built McDonalds's and the media frenzy that followed raced him forward to international recognition.

A significant event in the evolution of the union is the trip to the United States that began in Washington, meeting with local farming unions and ends in Seattle during the 1999 WTO protests. The first person experience of Heller, whom accompanies the paysans as a translator, presents a rich depiction of the incidents that took place with a mix of empowered social solidarity from many different international activist groups too the violence and severe crack down of police, that made it a historical political event. During this time the union becomes increasingly internationally involved with food-based social movements and Bové as its leader adopts Food Sovereignty as a central position, shifting the focus from food quality to social justice concerns around industrial agriculture and GMO's.

Heller completes the book with her disciplinary lens of Anthropology to understand what can be learned from the paysans for building a social movement. She identifies several factors that contributed to the movement, perhaps most notable is how Bové was able to assert the cultural knowledge of paysans as valid in itself, offsetting the need for scientific arguments relied on by the union in previous campaigns. Finally, Heller presents the Anthropology of Instrumentalism to articulate the trajectory of a post-industrial society where the 'logic' to turn life and elements to commodities is primary concern. The various actors in the paysan movement rise to counter this neoliberal logic uniting the paysans with food movements across the globe. Ultimately, Heller makes a significant contribution with this study to social movement discourses and union organization in addition to food justice and environmental issues.

Pamela Tudge Concordia University 